\title{
The effects of the selective mineralocorticoid receptor antagonist eplerenone on hepatic fibrosis induced by bile duct ligation in rat
}

\author{
TOMOMITSU MATONO, MASAHIKO KODA, SHIHO TOKUNAGA, \\ TAKAAKI SUGIHARA, MASARU UEKI and YOSHIKAZU MURAWAKI
} Division of Medicine and Clinical Science, Department of Multidisciplinary Internal Medicine,
Faculty of Medicine, Tottori University, 36-1 Nishi-machi, Yonago, 683-8504, Japan

Received January 12, 2010; Accepted February 17, 2010

DOI: 10.3892/ijmm_00000417

\begin{abstract}
The aim of this study was to examine the effects of eplerenone on hepatic fibrosis induced by bile duct ligation (BDL) in rat. Low- $(1.0 \mathrm{mg} / \mathrm{kg}$ body weight, BW) and high$(4.0 \mathrm{mg} / \mathrm{kg} \mathrm{BW})$ dose eplerenone was administered orally for 21 days immediately following BDL. Fibrosis was assessed by measuring the fibrotic area after Sirius red staining. Immunostaining for $\alpha$-smooth muscle actin (SMA), 4-hydroxy2-nonenal (4-HNE) and 8-hydroxy-2-deoxyguanosine (8-OHdG) was also carried out. Gene expression levels of procollagen-I, transforming growth factor- $\beta 1$ (TGF-ß1), connective tissue growth factor (CTGF), tissue inhibitor of metalloproteinases-1 (TIMP-1) and matrix metalloproteinase-13 (MMP-13) in the liver were examined by real-time reverse transcriptase polymerase chain reaction. Plasma angiotensin II (ATII) concentration was measured via radioimmunoassay. The area of hepatic fibrosis and $\alpha$-SMA positivity in the high-dose group was significantly decreased compared with that in the BDL group, but not in the low-dose group. 8-OHdG-positive cells in the low- and high-dose groups were significantly decreased compared with those in the BDL group. Immunostaining of 4-HNE in the high-dose group was significantly lower compared with that in the BDL group. Furthermore, TIMP-1 mRNA levels in the low- and high-dose groups were lower than that in the BDL group. The expression of TGF- 31 , CTGF, procollagen-1 and MMP-13 showed no differences. Plasma ATII concentration in the high-dose group was significantly decreased. Eplerenone attenuated the development of BDL-induced hepatic fibrosis by reducing oxidative stress, suppressing activated hepatic stellate cells and decreasing plasma ATII levels. Eplerenone may prove useful as an alternative treatment for antifibrosis therapy.
\end{abstract}

Correspondence to: Dr Masahiko Koda, Division of Medicine and Clinical Science, Department of Multidisciplinary Internal Medicine, Faculty of Medicine, Tottori University, 36-1 Nishi-machi, Yonago, 683-8504, Japan

E-mail: masakoda@grape.med.tottori-u.ac.jp

Key words: bile duct ligation, eplerenone, oxidative stress

\section{Introduction}

Angiotensin II (ATII) and aldosterone are the main effector peptides of the renin-angiotensin-aldosterone system (RAAS) and are known to be important mediators of hepatic fibrosis and portal hypertension (1-5). ATII and aldosterone stimulate the proliferation of hepatic stellate cells (HSC) and collagen synthesis, and are involved in the generation of reactive oxygen species (ROS) both in vitro and in vivo (6-8). ATII type 1 receptor blockers (ARB) and angiotensin-converting enzyme inhibitors (ACEI) have been reported to prevent the development of hepatic fibrosis in numerous animal (6-12) and human (13-15) studies. However, only a few studies examining the antifibrotic effects of aldosterone blockers have been reported to date. The results arising from these studies have proven to be controversial $(1,2,5)$. Fujisawa et al $(5)$ reported that spironolactone prevented pig serum-induced hepatic fibrosis in rats, while Oberti et al (2) showed that spironolactone did not produce any anti-fibrotic effects during bile duct ligation (BDL)-induced hepatic fibrosis.

The novel aldosterone blocker eplerenone has been shown to exhibit a high specificity for mineralocorticoid receptors $(16,17)$. While the efficacy and safety of eplerenone in the treatment of hypertension have been demonstrated in a number of previous studies (18-20), no studies have reported the effects of eplerenone on hepatic fibrosis. Cholestatic fibrosis induced by BDL has been shown to be a suitable experimental model of human liver diseases including primary and secondary biliary cirrhosis and primary sclerosing cholangitis. Our previous study has demonstrated that components of the RAAS are up-regulated during BDL-induced liver fibrosis, and that RAAS plays an important role in the progression of hepatic fibrosis (6). In addition, oxidative stress and pro-inflammatory cytokinesis play essential roles in the development of cholestatic liver fibrosis (21). In the present study, we examined the effects of eplerenone during cholestatic liver fibrosis induced by BDL in rats.

\section{Materials and methods}

Animals. Male Wistar rats were obtained from Japan SLC (Shizuoka, Japan) and housed in a room maintained at a controlled temperature of $24 \pm 2^{\circ} \mathrm{C}$ under a 12-h light-dark cycle. Animals were provided standard pellet chow and water 
ad libitum. BDL operations were performed under anesthesia following a $50 \mathrm{mg} / \mathrm{kg}$ intraperitoneal injection of pentobarbital (Dainippon Pharmaceutical, Osaka, Japan). All experiments were carried out in accordance with the Animal Experimentation Guidelines of Tottori University.

Establishment of the BDL model and administration of eplerenone. Wistar male rats (192-231 g body weight) were used in this study and hepatic fibrosis was induced by BDL as previously described $(4,6)$. We used the 3 -week-old BDL rat model to study the effects of eplerenone on the development of hepatic fibrosis. Rats in the BDL + low-dose eplerenone group (low-dose group) were administered eplerenone orally at a dose of $1.0 \mathrm{mg} / \mathrm{kg}$, which is an ordinary dose for humans, via a gastric tube every day for 21 days immediately following the operation (survival rate, $n=8 / 10$ ). Rats in the $\mathrm{BDL}+$ highdose eplerenone group (high-dose group) were administered eplerenone orally at a dose of $4.0 \mathrm{mg} / \mathrm{kg}$ every day for 21 days immediately following the operation (survival rate, $n=9 / 10$ ). The BDL group received vehicle for the same period (survival rate, $\mathrm{n}=9 / 10)$. Vitamin $\mathrm{K}(5 \mathrm{mg} / \mathrm{kg}$ ) was injected intramuscularly once a week to all groups to prevent the occurrence of fatal hemorrhage (22). In addition, six rats were carried out by sham-operation.

On day 21, animals were sacraficed under pentobarbital anesthesia and blood was collected from the inferior vena cava. Serum and plasma samples were frozen and stored at $-80^{\circ} \mathrm{C}$ until required. Total serum bilirubin (T-bil), aspartate aminotransferase (AST) and alanine aminotransferase (ALT) levels were measured using an autoanalyzer (7170, Hitachi, Tokyo, Japan). Plasma renin, ATII and aldosterone levels were measured using a radioimmunoassay. The liver was also collected, weighed, snap-frozen in liquid nitrogen and stored at $-80^{\circ} \mathrm{C}$ until required. Liver specimens were also fixed in $10 \%$ buffered formalin and embedded in paraffin for histological analysis.

Assay for hepatic hydroxyproline (Hyp) content. Hepatic tissue (200 mg wet weight) was hydrolyzed in $4 \mathrm{ml}$ of $6 \mathrm{~N} \mathrm{HCl}$ at $105^{\circ} \mathrm{C}$ overnight. Hydrolysate was evaporated under a vacuum four times. Sediment was redissolved in distilled water, mixed with activated charcoal for decolorization, and then filtered. The solution was kept in the acidic range by adjustment to $\mathrm{pH} 5.0$ and evaporated under a vacuum, and sediment was redissolved in distilled water, supplemented with $2 \mathrm{ml}$ of isopropanol, and incubated with $1 \mathrm{ml}$ of $7 \%$ chloramine-T solution for $5 \mathrm{~min}$ at room temperature. Ehrlich's solution ( $2 \mathrm{ml}$ ), consisting of $1.76 \mathrm{~g}$ of $\mathrm{p}$-dimethylaminobenzaldehyde dissolved in $4.08 \mathrm{ml}$ of $60 \%$ perchloric acid and $95.5 \mathrm{ml}$ of isopropanol, was added, and the mixture was incubated at $60^{\circ} \mathrm{C}$ for $10 \mathrm{~min}$. After cooling, the absorbance measured at $562 \mathrm{~nm}$ (23).

Measurement of the hepatic fibrosis area. Formalin-fixed, paraffin-embedded liver ( $4 \mu \mathrm{m}$-thick sections) were stained with picrosirius red (Sigma-Aldrich, St. Louis, MO) and counter-stained with fast green (Sigma-Aldrich). The area of hepatic fibrosis was then measured in 10 randomly selected fields/section (magnification $\mathrm{x} 100$ ) per specimen using WinRoof version 5.71 (Mitani Shoji, Fukui, Japan).
Table I. Primers used for real-time PCR.

\begin{tabular}{|c|c|c|}
\hline Gene & Accession no. & Primers \\
\hline$\beta$-actin & ВC063166 & $\begin{array}{l}\text { F: 5'-CCCGCGAGT } \\
\text { ACAACCTTCT-3' } \\
\text { R: 5'-CGTCATCC } \\
\text { ATGGCGAACT-3' }\end{array}$ \\
\hline Procollagen-I & Z78279 & $\begin{array}{l}\text { F: 5'-ATGTTCAGCT } \\
\text { TTGTGGACCTC-3' } \\
\text { R: 5'-GCAGCTGAC } \\
\text { TTCAGGGATGT-3' }\end{array}$ \\
\hline TGF- $\beta 1$ & X52498 & $\begin{array}{l}\text { F: 5'-CCTGGAAAG } \\
\text { GGCTCAACAC-3' } \\
\text { R: 5'-CAGTTCTTCTC } \\
\text { TGTGGAGCTGA-3' }\end{array}$ \\
\hline TIMP-1 & U06179 & $\begin{array}{l}\text { F: 5'-CAGCAAAAG } \\
\text { GCCTTCGTAAA-3' } \\
\text { R: 5'-TGGCTGAAC } \\
\text { AGGGAAACACT-3' }\end{array}$ \\
\hline CTGF & AB023068 & $\begin{array}{l}\text { F: 5'-GCTGACCTAGAG } \\
\text { GAAAACATTAAGA-3' } \\
\text { R: 5'-CCCGGTAGG } \\
\text { TCTTCACACTG-3' }\end{array}$ \\
\hline MMP-13 & M60616 & $\begin{array}{l}\text { F: 5'-GGACAAGC } \\
\text { AGCTCCAAAGG-3' } \\
\text { R: 5'-GGTCCAGA } \\
\text { CCGAGGGAGT-3' }\end{array}$ \\
\hline
\end{tabular}

F, forward; R, reverse; TGFß-1, transforming growth factor $B 1$; TIMP-1, tissue inhibitor of metalloproteinases-1; CTGF, connective tissue growth factor; MMP, matrix metalloproteinas.

$\alpha$-smooth muscle actin ( $\alpha$-SMA) immunostaining. Immunohistochemical staining of $\alpha$-SMA was performed using anti- $\alpha$-SMA antibody (Dako A/S, Glostrup, Denmark). To assess the activation grade of hepatic stellate cells, the area of $\alpha$-SMA staining was analyzed using WinRoof version 5.71 in 10 randomly selected fields/section (magnification x100) per specimen.

RNA extraction and reverse transcription polymerase chain reaction $(P C R)$ analysis. Tissue samples were homogenized and total RNA was extracted using the RNeasy Mini Kit (Qiagen, Hilden, Germany). RNA concentration was determined by measuring absorbance at $260 \mathrm{~nm}$, and the quality of RNA was verified by electrophoresis on ethidium bromide-stained $1 \%$ agarose gels. Total RNA $(\sim 2 \mu \mathrm{g})$ was then reverse transcribed (RT) in a final volume of $11.5 \mu \mathrm{l}$ containing $4 \mu \mathrm{l}$ of $5 \mathrm{x}$ standard buffer, $2 \mu 1$ of $0.1 \mathrm{M}$ dTT, $1 \mu 1$ of SuperScript II RNase HReverse Transcriptase (Invitrogen, Carlsbad, CA), $2 \mu 1$ of $10 \mathrm{M}$ MdNTPs (Promega, Madison, WI), $1 \mu 1$ of $50 \mathrm{pmol} / \mu 1$ Random Primer (Promega), $0.5 \mu 1$ of $100 \mathrm{pmol} / \mu 1$ Oligo (dt)15 Primer (Promega) and $1 \mu \mathrm{l}$ of $40 \mathrm{U} / \mu \mathrm{l}$ ribonuclease inhibitor (Wako Pure Chemical Industries, Ltd., Osaka, Japan). Samples were then incubated at $37^{\circ} \mathrm{C}$ for $60 \mathrm{~min}, 95^{\circ} \mathrm{C}$ for $5 \mathrm{~min}$ and cooled to $4^{\circ} \mathrm{C}$ for $5 \mathrm{~min}$. 
Table II. Biochemical data at 3 weeks following BDL.

\begin{tabular}{lcccc}
\hline & $\begin{array}{c}\text { Sham } \\
\mathrm{n}=6\end{array}$ & $\begin{array}{c}\text { BDL group } \\
\mathrm{n}=9\end{array}$ & $\begin{array}{c}\text { Low-dose group } \\
\mathrm{n}=8\end{array}$ & $\begin{array}{c}\text { High-dose group } \\
\mathrm{n}=9\end{array}$ \\
\hline Serum T-bil (mg/dl) & 0 & $2.1 \pm 1.8$ & $2.1 \pm 1.9$ & $3.0 \pm 1.9$ \\
Serum AST (IU/l) & $109 \pm 45$ & $331 \pm 218$ & $378 \pm 262$ & $533 \pm 322$ \\
Serum ALT (IU/l) & $45 \pm 18$ & $58 \pm 16$ & $59 \pm 22$ & $108 \pm 53^{\mathrm{a}}$ \\
Plasma Renin (pg/ml) & & $33.6 \pm 8.5$ & $21.9 \pm 9.9$ & $26.7 \pm 11.5$ \\
Plasma Angiotensin-II (pg/ml) & & $237 \pm 145$ & $170 \pm 74$ & $120 \pm 45^{\mathrm{a}}$ \\
Plasma Aldosterone (pg/ml) & & $750 \pm 500$ & $509 \pm 274$ & $757 \pm 539$ \\
\hline
\end{tabular}

Values are presented as the mean \pm standard deviation; T-bil, total bilirubin; AST, aspartate aminotransferase; ALT, alanine aminotransferase. ${ }^{\mathrm{a}} \mathrm{p}<0.05$, compared with the BDL group determined by Mann-Whitney test.

Table III. Hydroxyproline content and expression of procollagen I, TGF- $ß 1$, TIMP-1, CTGF and MMP-13 mRNA in the liver at 3 weeks following BDL.

\begin{tabular}{|c|c|c|c|c|}
\hline & $\begin{array}{c}\text { Sham } \\
n=6\end{array}$ & $\begin{array}{c}\text { BDL group } \\
n=9\end{array}$ & $\begin{array}{l}\text { Low-dose group } \\
n=8\end{array}$ & $\begin{array}{l}\text { High-dose group } \\
n=9\end{array}$ \\
\hline Hyp ( $\mu \mathrm{g} / \mathrm{g}$ wet liver $)$ & $129 \pm 89$ & $602 \pm 152$ & $541 \pm 278$ & $446 \pm 169^{b}$ \\
\hline Procollagen I (x10-2) & & $18.1 \pm 6.9$ & $5.5 \pm 4.3$ & $4.8 \pm 4.6$ \\
\hline TGF- $\beta 1\left(\times 10^{-2}\right)$ & & $2.7 \pm 0.9$ & $2.2 \pm 0.7$ & $2.6 \pm 1.1$ \\
\hline TIMP-1 (x10-2) & & $5.1 \pm 1.1$ & $2.3 \pm 1.7^{\mathrm{a}}$ & $3.6 \pm 2.1^{\mathrm{b}}$ \\
\hline CTGF (x10-2) & & $5.0 \pm 3.0$ & $3.0 \pm 3.0$ & $4.0 \pm 3.0$ \\
\hline MMP-13 (x10-2) & & $1.2 \pm 1.3$ & $1.1 \pm 0.5$ & $1.4 \pm 0.7$ \\
\hline
\end{tabular}

Values are presented as the mean \pm standard deviation. Hyp, hydroxyproline; TGF- $\beta 1$, transforming growth factor- $\beta 1$; TIMP-1, tissue inhibitor of metalloproteinases-1; CTGF, connective tissue growth factor; MMP-13, matrix metalloproteinase-13. ${ }^{\text {a }} \mathrm{p}<0.01$ and ${ }^{\mathrm{b}} \mathrm{p}<0.1$, compared with the BDL group.

Real-time PCR. Quantitative real-time PCR was performed in a final volume of $10 \mu 1$ containing $4.1 \mu 1 \mathrm{PCR}$ grade water, $1 \mu 1$ Universal Probe Library probe (Roche, Tokyo, Japan), $0.2 \mu \mathrm{l}$ forward primer $(10 \mu \mathrm{M}), 0.2 \mu \mathrm{l}$ reverse primer $(10 \mu \mathrm{M})$, $2 \mu 1$ Light Cycler TaqMan Master (Roche) and $2.5 \mu \mathrm{l}$ cDNA. The mRNA levels of transforming growth factor- 31 (TGF-B1) (GenBank, X52498), connective tissue growth factor (CTGF, GenBank; AB023068), tissue inhibitor of metalloproteinases-1 (TIMP-1, GenBank, U06179), matrix metalloproteinase-13 (MMP-13, GenBank, M60616) and procollagen-type I (GenBank, Z78279) were assessed using the Light Cycler Fast Start DNA Master SYBR Green 1 real-time PCR assay (Roche) with $B$-actin (BC063166) as the housekeeping gene (Table I). The thermal cycle conditions were as follows, hold at $95^{\circ} \mathrm{C}$ for $10 \mathrm{~min}$, repeat 45 cycles of $95^{\circ} \mathrm{C}$ for $30 \mathrm{sec}$ and $60^{\circ} \mathrm{C}$ for $1 \mathrm{~min}$.

Analysis of oxidative stress and lipid peroxidation. Oxidative stress was evaluated by measuring the levels of 8-hydroxy-2deoxyguanosine $(8-\mathrm{OHdG})$, a marker of oxidative DNA damage (24), using immunohistochemical staining and enzymelinked immunosorbent assay (ELISA). Immunohistochemical staining of 8-OHdG was performed using an anti-8-OHdG monoclonal antibody (Nikken Seil, Shizuoka, Japan) in accordance with the manufacturer's instructions. Analysis of immunopositive cells was carried out in 10 intralobular ocular fields (magnification $\mathrm{x} 400$ ) per specimen, and was expressed as a percentage of fields using the WinRoof version 5.71.

For ELISA, frozen liver tissues were homogenized and DNA was extracted using the Nal method and the DNeasy Mini Kit. After the DNA pellet was dissolved in TE buffer, $50 \mu \mathrm{g}$ of DNA was digested with nuclease P1 (Sigma-Aldrich) and alkaline phosphatase (Sigma-Aldrich), and centrifuged at $14,000 \mathrm{~g}$ for $10 \mathrm{~min}$ through a Microcone YM-10 filter (Millipore, Bedford, MA) according to the manufacturer's instructions. The 8-OHdG content in the extracted DNA solution was then determined using the highly sensitive 8-OHdG check ELISA kit (Nikken Seil). The absorbance of each well was measured at $450 \mathrm{~nm}$ using a microplate reader.

Thiobarbituric acid reactive substance (TBARS) was quantified as described previously (25). Immunohistochemical staining of 4-hydroxy-2-nonenal (4-HNE) was performed using an anti-4-HNE monoclonal antibody (Nikken Seil) according to the manufacturer's instructions. Histological images of 4-HNE staining were randomly selected in 10 fields/section (magnification $\mathrm{x} 100$ ) per specimen and classified into four grades based on the extent of 4-HNE-positive staining in the cytoplasm (26).

Statistical analysis. The Mann-Whitney test was used to assess statistical significance among all groups. All statistical tests 

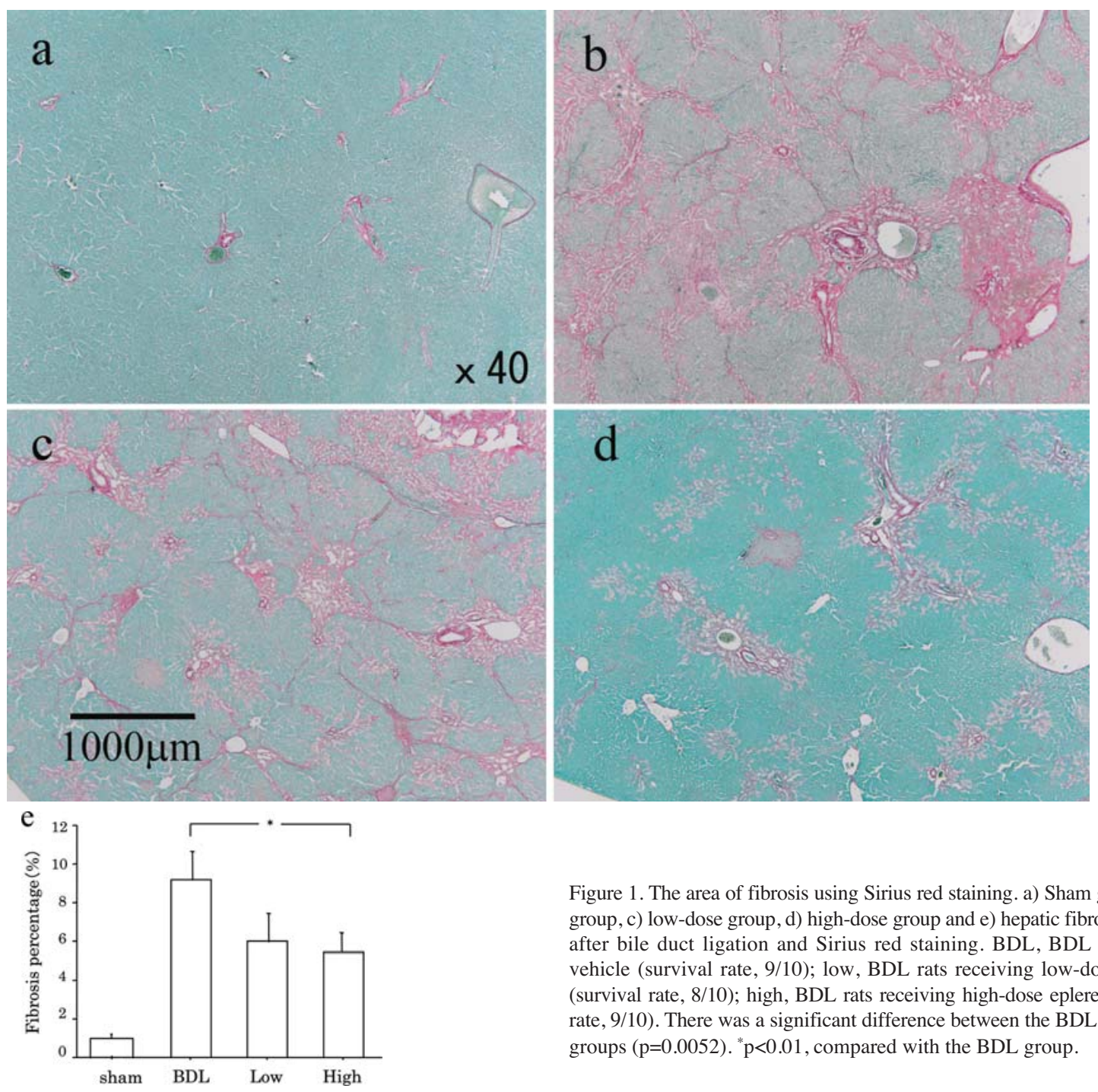

Figure 1. The area of fibrosis using Sirius red staining. a) Sham group, b) BDL group, c) low-dose group, d) high-dose group and e) hepatic fibrosis percentage after bile duct ligation and Sirius red staining. BDL, BDL rats receiving vehicle (survival rate, 9/10); low, BDL rats receiving low-dose eplerenone (survival rate, 8/10); high, BDL rats receiving high-dose eplerenone (survival rate, 9/10). There was a significant difference between the BDL and high-dose groups $(\mathrm{p}=0.0052) .{ }^{*} \mathrm{p}<0.01$, compared with the BDL group.

were carried out using StatView for Windows (SAS Institute, Cary, NC). Values of $\mathrm{p}<0.05$ were considered significant.

\section{Results}

Biochemical data 3 weeks following BDL. Serum ALT in the high-dose group was significantly higher than that in the BDL and low-dose group $(\mathrm{p}<0.05)$. Serum bilirubin and serum AST levels were not increased in the high-dose group. Plasma ATII concentration in the high-dose group was significantly lower than that in the BDL group $(\mathrm{p}<0.05)$, while plasma renin and aldosterone levels remained unchanged (Table II).

Effects of eplerenone on BDL-induced hepatic fibrosis. Histological analysis revealed that eplerenone inhibited the progression of hepatic fibrosis when compared with the BDL group. The hepatic hydroxyproline content in the high-dose group tended to be lower than that in the control group (control, $602 \pm 152 \mu \mathrm{g} / \mathrm{g}$ wet liver; low-dose group, $541 \pm 278 \mu \mathrm{g} / \mathrm{g}$ wet liver; high-dose group, $446 \pm 169 \mu \mathrm{g} / \mathrm{g}$ wet liver, $\mathrm{p}=0.08$, Table III). Semi-quantitative measurement of the area of fibrosis using Sirius red staining demonstrated that eplerenone administration reduced the progression of liver fibrosis, especially in the high-dose group (sham group, $0.62 \pm 0.20 \%$;
BDL group, 9.8 $\pm 3.6 \%$; low-dose group $6.8 \pm 4.0 \%$; high-dose group, $4.8 \pm 2.5 \%, \mathrm{p}=0.0052$, Fig. 1a-e). Administration of high-dose eplerenone also reduced the area of positive $\alpha$-SMA immunostaining (sham group, $0.66 \pm 0.11 \%$; BDL group, $4.9 \pm 2.0 \%$, low-dose group $4.6 \pm 2.1 \%$; high-dose group, $2.6 \pm 2.0 \%, p=0.032$, Fig. 2a-e).

Eplerenone administration ablated any increases in mRNA levels of procollagen I in a dose-dependent manner. However, these changes were not significant. mRNA expression of TIMP-1 in the low-dose $(\mathrm{p}=0.001)$ and high-dose $(\mathrm{p}=0.08)$ groups were significantly lower than that in the BDL group. Gene expression levels of TGF- $\beta 1$, CTGF and MMP-13 did not differ among the three groups (Table III).

Eplerenone administration markedly reduced the number of 8-OHdG-positive cells present in the liver samples (Table IV). 8 -OHdG-positive cells in the low-dose $(51.6 \pm 7.9 \%$; $\mathrm{p}=0.0005)$ and high-dose $(53.4 \pm 7.3 \%$; $=0.0007)$ groups were significantly decreased compared to those in the BDL group $(68.7 \pm 8.7 \%$; Fig. 3a-e, Table IV). The total $8-\mathrm{OHdG}$ DNA content also tended to decrease following eplerenone administration (Table IV).

4-HNE protein expression in the high-dose group (2.1 \pm 0.69$)$ was lower than that in the BDL group $(2.9 \pm 0.87)$ following immunohistochemical staining $(\mathrm{p}=0.046)$. The low-dose group 

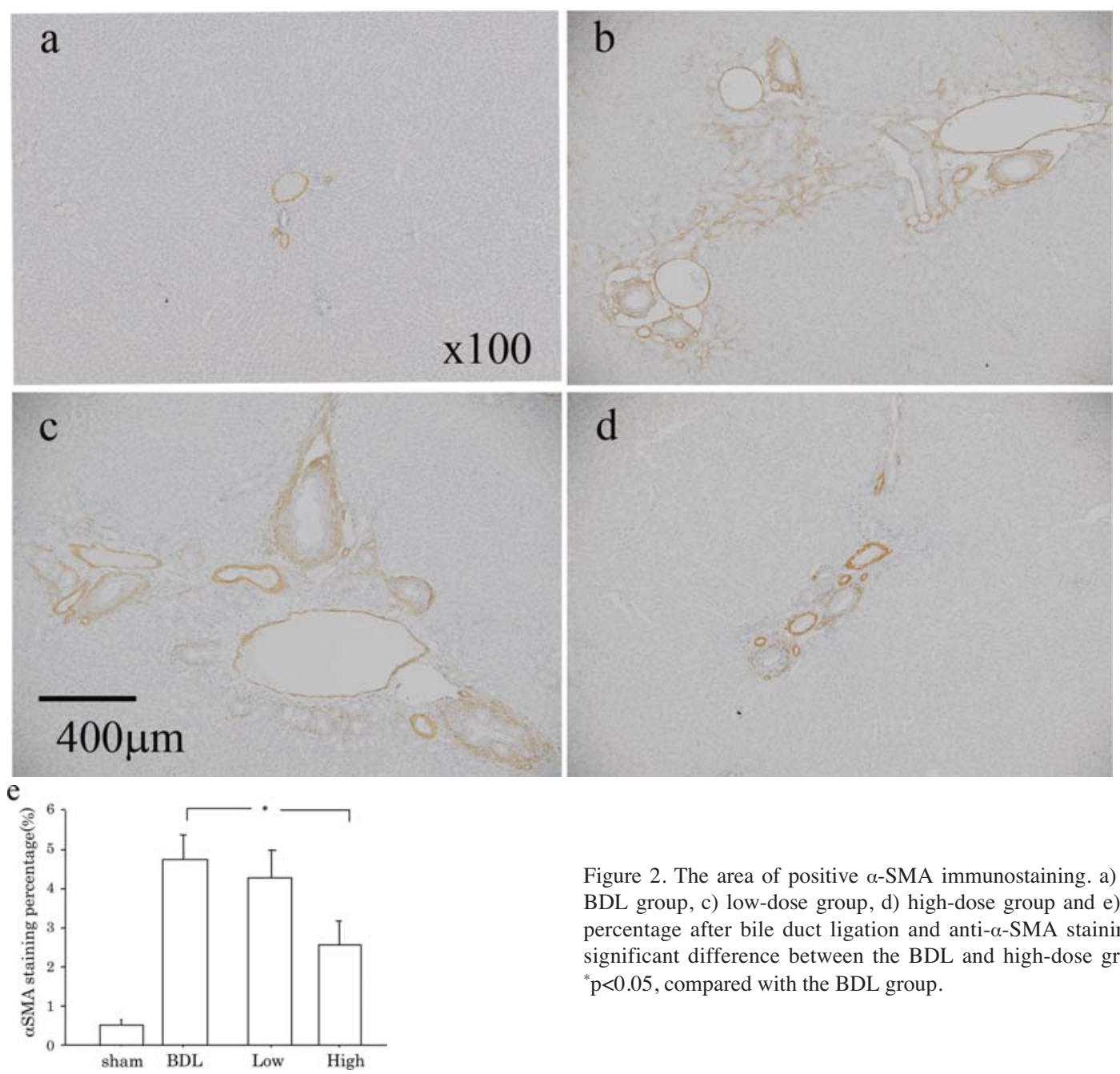

Figure 2. The area of positive $\alpha$-SMA immunostaining. a) Sham group, b) BDL group, c) low-dose group, d) high-dose group and e) hepatic fibrosis percentage after bile duct ligation and anti- $\alpha$-SMA staining. There was a significant difference between the BDL and high-dose groups $(\mathrm{p}=0.032)$. ${ }^{*} \mathrm{p}<0.05$, compared with the BDL group.

Table IV. Analysis of lipid peroxidation and oxidative stress.

\begin{tabular}{lcccc}
\hline & $\begin{array}{c}\text { Sham } \\
\mathrm{n}=6\end{array}$ & $\begin{array}{c}\text { BDL group } \\
\mathrm{n}=9\end{array}$ & $\begin{array}{c}\text { Low-dose group } \\
\mathrm{n}=8\end{array}$ & $\begin{array}{c}\text { High-dose group } \\
\mathrm{n}=9\end{array}$ \\
\hline TBARS (nmol/ml) & $21.5 \pm 3.3$ & $19.4 \pm 4.1$ & $16.4 \pm 5.3$ & $20.1 \pm 7.1$ \\
4-HNE (grade) & $0.17 \pm 0.41$ & $2.9 \pm 0.87$ & $2.9 \pm 0.69$ & $2.1 \pm 0.69^{\mathrm{a}}$ \\
8-OHdG DNA content $(\mathrm{pg} / \mu \mathrm{g})$ & & $0.28 \pm 0.14$ & $0.22 \pm 0.16$ & $0.19 \pm 0.11$ \\
8-OHdG IHC $(\%)$ & $5.2 \pm 2.4$ & $68.7 \pm 8.7$ & $51.6 \pm 7.9^{\mathrm{b}}$ & $53.4 \pm 7.3^{\mathrm{b}}$ \\
\hline
\end{tabular}

Values are presented as the mean \pm standard deviation. TBARS, thiobarbituric acid reactive substance of hepatic tissue; 4-HNE, average 4hydroxy-2-nonenal staining grade; 8-OHdG DNA, 8-OHdG DNA content of hepatic tissue; 8-OHdG IHC, percentage of 8-OHdG stained cells. ${ }^{\mathrm{a}} \mathrm{p}<0.05$ and ${ }^{\mathrm{b}} \mathrm{p}<0.001$, compared with the BDL group.

$(2.9 \pm 0.69)$ did not demonstrate this reduction (Fig. 4a-e, Table IV). Hepatic TBARS, a marker of lipid peroxidation, did not differ among the three groups (Table IV).

\section{Discussion}

The present study demonstrated that high-dose administration of eplerenone, a specific mineralocorticoid receptor blocker, attenuated the progression of BDL-induced hepatic fibrosis, and slightly reduced the expression of collagen-1 and significantly reduced that of TIMP-1. These findings suggested that eplerenone ameliorated hepatic fibrosis through additive effect of decrease in collagen synthesis and decreased in collagen degradation. Indeed, in vitro studies have demonstrated that aldosterone induced the synthesis of procollagen type I in rat stellate cells (27). Canrenone is an anti-aldosterone drug that has been shown to attenuate cell proliferation and migration induced by platelet-derived growth factor (PDGF) and procollagen types I and IV, as well as fibronectin induced by TGF- $\beta$ in human stellate cells (10). In addition, in vivo studies have also demonstrated the antifibrotic effects of spironolactone, a mineralocorticoid receptor antagonist, in pig 

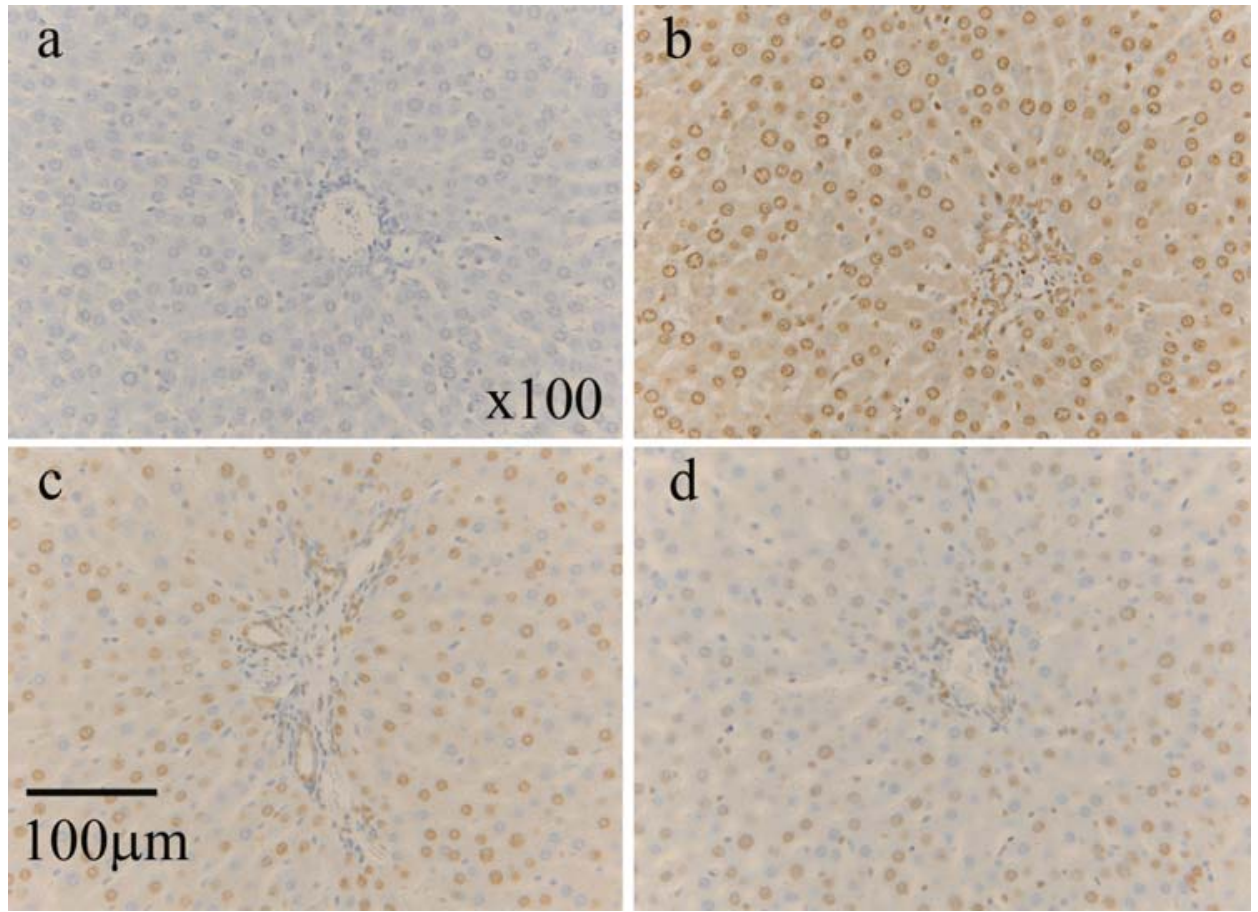

e

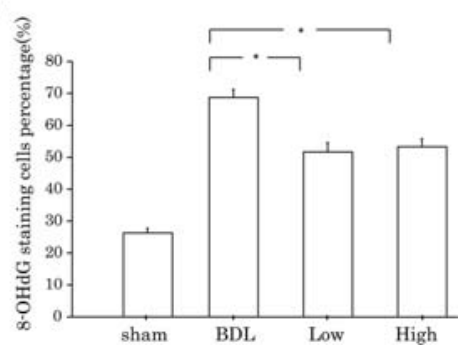

Figure 3. Oxidative stress for 8-OHdG immunohistochemical staining. a) Sham group, b) BDL group, c) low-dose group, d) high-dose group and e) immunohistochemical staining with an anti-8-OHdG monoclonal antibody. 8-OHdG percentage was significantly reduced in the low- and high-dose groups compared with the BDL group. ${ }^{*} \mathrm{p}<0.001$, compared with the BDL group.
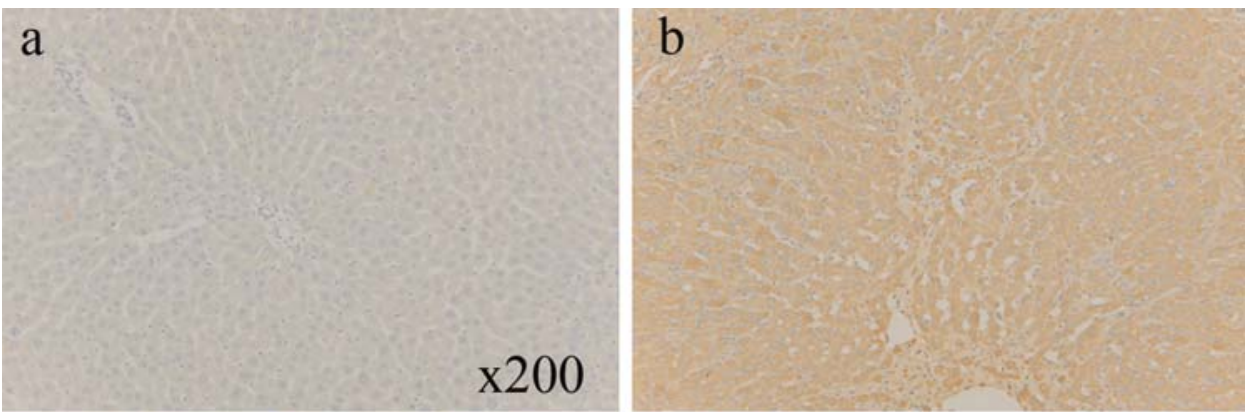

C

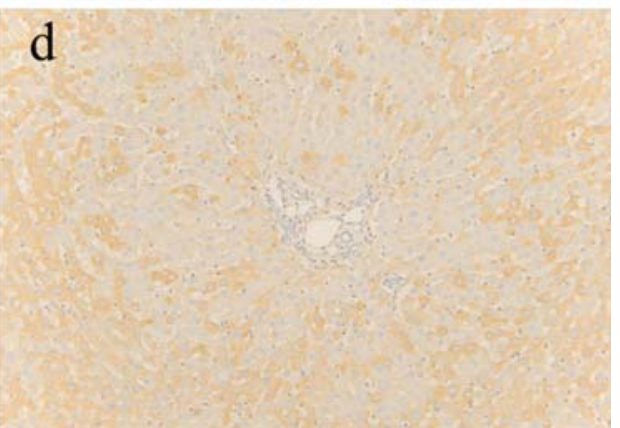

\section{$\overline{200 \mu \mathrm{m}}$}

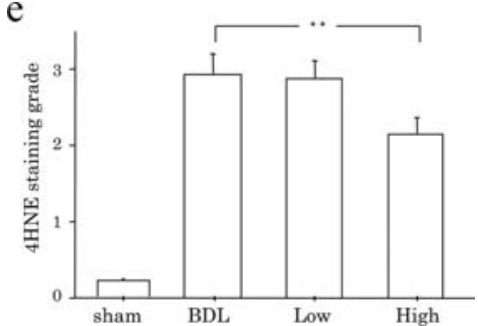

Figure 4. Lipid peroxidation for 4-HNE immunohistochemical staining. a) Sham group, b) BDL group, c) low-dose group, d) high-dose group and e) immunohistochemical staining grade of 4-HNE expression. The high-dose group was significantly reduced compared with the BDL group. ${ }^{*} \mathrm{p}<0.001$ and ${ }^{* *} \mathrm{p}<0.05$, compared with the BDL group. 
serum-induced hepatic fibrosis. The present study also showed that eplerenone attenuated the activation of HSC. These results suggested that eplerenone affects HSC and exhibits preventive effects on the development of liver fibrosis.

In the present study, we also found that eplerenone administration resulted in a reduction in $8-\mathrm{OHdG}$ expression, a marker of oxidative stress, and a decrease in the staining of 4-HNE, a marker of lipid peroxidation. It is well established that oxidative stress and lipid peroxidation are involved in the pathogenesis of BDL-induced liver fibrosis (28). Indeed, we have showed that $8-\mathrm{OHdG}$ and $4-\mathrm{HNE}$ expression was significantly increased in the liver of BDL rats compared with sham rats as well as our previous reports $(6,8)$. In contrast, antioxidant factors such as glutathione, as well as the activity of GSH peroxidase and catalase, have been reported to be low in the liver of BDL rats (28). Furthermore, it has been reported that aldosterone accelerated oxidative stress in cell culture (29). Therefore, the antifibrotic effects of eplerenone appear to be due to the suppression of oxidative stress and lipid peroxidation.

In addition, we also demonstrated that eplerenone decreased HSC activation, but did not alter mRNA expression levels of TGF-B1 and CTGF. Recently, inhibitors of ATII have been suggested to function as antifibrotic drugs, while ARB has been shown to inhibit both the activation of HSC and the expression of profibrogenic cytokines such as TGF- 11 and CTGF (10). These differences in pharmacological action may therefore influence the antifibrotic effects. In fact, it appears that the antifibrotic effects of eplerenone are weaker than those in our previous study demonstrating the antifibrotic effects of ARB (6).

Interestingly, high doses of eplerenone resulted in a reduction in serum ATII levels. ATII exhibits powerful profibrogenic effects, generates ROS and stimulates the proliferation of HSC. Recent studies have reported that aldosterone induces ACE gene expression in rat cardiomyocytes (30) and that aldosterone reduces the gene expression of ACE-2, which compared angiotensin II to angiotensin 1-7 by separating phenylalanine (31). Furthermore, eplerenone administration completely blocked increases in ACE mRNA levels and the reduction in ACE2 mRNA levels due to the presence of aldosterone. Thus, eplerenone may abrogate several harmful effects of ATII via the reduction of serum ATII levels.

In conclusion, we demonstrated that eplerenone treatment attenuated the development of BDL-induced hepatic fibrosis by reducing oxidative stress, suppressing activation of HSC. Thus, eplerenone may prove useful as an alternative drug for antifibrosis therapy.

\section{References}

1. Oberti F, Rifflet H, Maiga MY, Pilette C, Gallois Y, Douay O, Jeune JJ, Saumet JL and Cales P: Prevention of portal hypertension by propranolol and spironolactone in rats with bile duct ligation. J Hepaol 26: 167-173, 1997.

2. Oberti F, Pilette C, Rifflet H, Maiga MY, Moreau A, Gallois Y, Girault A, Bouil A, Jeune JJ, Saumet JL, Feldmann G and Cales P: Effects of simvastatin, pentxifylline and spironolactone on hepatic fibrosis and portal hypertension in rats with bile duct ligation. $\mathbf{J}$ Hepaol 26: 1363-1371, 1997.

3. Yoshiji H, Kuriyama S, Yoshii J, Ikenaka Y, Noguchi R, Nakatani T, Tsujinoue $\mathrm{H}$ and Fukui H: Angiotensin-II type 1 receptor interaction is a major regular for liver fibrosis development in rats. Hepatology 34: 745-750, 2001.
4. Struthers AD and MacDonald TM: Review of aldosterone- and angiotensin II-induced target organ damage and prevention. Cardiovasc Res 61: 663-670, 2004.

5. Fujisawa G, Muto S, Okada K, Kusano E and Ishibashi S: Mineralocorticoid receptor antagonist spironolactone prevents pig serum-induced hepatic fibrosis in rats. Transl Res 148: 149-156, 2006.

6. Ueki M, Koda M, Yamamoto S, Matsunaga Y and Murawaki Y: Preventive and therapeutic effects of angiotensin II type 1 receptor blocker on hepatic fibrosis induced by bile duct ligation in rats. J Gastroenterol 41: 996-1004, 2006.

7. Remuzzi G, Cattaneo D and Perico N: The aggravating mechanisms of aldosterone on kidney fibrosis. J Am Soc Nephrol 19: 1459-1462, 2008.

8. Ueki M, Koda M, Matono T, Sugihara T, Maeda K and Murawaki Y: Preventive and therapeutic effect of perindopril on hepatic fibrosis induced by bile duct ligation in rats. Mol Med Rep 2: 857-864, 2009.

9. Jonsson JR, Clouston AD, Ando Y, Kelemen LI, Horn MJ, Adamson MD, Purdie DM and Powell EE: Angiotensinconverting enzyme inhibition attenuates the progression of rat hepatic fibrosis. Gastroenterology 121: 148-155, 2001.

10. Caligiuri A, De Franco RM, Romanelli RG, Gentilini A, Meucci M, Failli P, Mazzetti L, Rombouts K, Geerts A, Vanasia M, Gentilini P, Marra F and Pizani M: Antifibrogenic effects of canrenone, an antialdosteronic drug, on human hepatic stellate cells. Gatoroenterology 124: 504-520, 2003.

11. Kurikawa N, Suga M, Kuroda S, Yamada K and Ishikawa H: An angiotensin II type 1 receptor antagonist, olmesartan medoxomil, improves experimental liver fibrosis by suppression of proliferation and collagen synthesis in activated hepatic stellate cells. Br J Pharmacol 139: 1085-1094, 2003.

12. Kim MY, Baik SK, Park DH, Jang YO, Suk KT, Yea CJ, Lee IY, Kim JW, Kim HS, Kwon SO, Cho MY, Ko SB, Chang SJ, $\mathrm{Um} \mathrm{SH}$ and Han KH: Angiotensin recetor blockers are superior to angiotensin-converting enzyme inhibitors in the suppression of hepatic fibrosis in a bile duct-ligated rat model. J Gastroenterol 43: 889-896, 2008.

13. Terui Y, Saito T, Watanabe H, Togashi H, Kawata S, Kamada Y and Sakuta S: Effect of angiotensin receptor antagonist on liver fibrosis in early stages of chronichepatitis C. Hepatology 36: $1022,2002$.

14. Yokohama S, Yoneda M, Haneda M, Okamoto S, Okada M, Aso K, Hasegawa T,Tokusashi Y, Miyokawa N and Nakamura K: Therapeutic efficacy of an angiotensin II receptor antagonist in patients with nonalcoholic steatohepatitis. Hepatology 40: 1222-1225, 2004.

15. Ueki M, Koda M, Shimizu T, Mitsuta A, Yamamoto T and Murawaki Y: Effect of an angiotensin-II type-1 receptor blocker, candesartan on hepatic fibrosis in chronic hepatitis C: a prospective study. Hepatogastroenterology 56: 1100-1104, 2009.

16. White WB, Carr AA, Krause S, Jordan R, Roniker B and Oigman W: Assessment of the novel selective aldosterone blocker eplerenone using ambulatory and clinical blood pressure in patients with systemic hypertension. Am J Cardiol 92: 38-42, 2003.

17. Flack JM, Oparil S, Pratt JH, Roniker B, Garthwaite S, Kleiman JH, Yang Y, Krause SL, Workman D and Saunders E: Efficacy and tolerability of eplerenone and losartan in hypertensive black and white patients. J Am Coll Cardiol 41: 1148-1155, 2003.

18. Nehme J, Mercier N, Labat C, Benetos A, Safar ME, Delcayre C and Lacolley P: Difference between cardiac and arterial fibrosis and stiffness in aldosterone-salt rats: effect of eplerenone. J Renin Angiotensin Aldosterone Syst 7: 31-39, 2006

19. Rastogi S, Mishra S, Zaca V, Alesh I, Gupta RC, Goldstein S and Sabbah HN: Effect of long-term monotherapy with the aldosterone receptor blocker eplerenone on cytoskeletal proteins and matrix metlloproteinases in dogs with heart failure. Cardiovasc Drugs Ther 21: 415-422, 2007.

20. Nishioka T, Suzuki M, Onishi K, Takakura N, Inada H, Yoshida T, Hiroe $\mathrm{M}$ and Imanaka-Yoshida K: Eplerenone attenuates myocardial fibrosis in the angiotensin II-induced hypertensive mouse: involvement of tenascin- $\mathrm{C}$ induced by aldosterone-mediated inflammation. J Cardiovasc Pharmacol 49: 261-268, 2007.

21. Lee BS, Kim NJ, Jeong HY, Lee HY, Kang DY and Noh SM: Change in serum cytokine concentration. A morphological study of liver cirrhosis induced by common bile duct ligation in rats. Korean J Intern Med 18: 6-12, 2003.

22. Akimoto T, Hayashi N, Adachi M, Kobayashi N, Zhang XJ, Ohsuga $\mathrm{M}$ and Katsuta $\mathrm{Y}$ : Viability and plasma vitamin $\mathrm{K}$ levels in the common bile duct-ligated rats. Exp Anim 54: 155-161, 2005. 
23. Murawaki Y and Hirayama C: Hepatic collagenolytic cathepsin in patients with chronic liver disease. Clin Chim Acta 108: 121-128, 1980.

24. Wu LL, Chiou CC, Chang PY and Wu JT: Urinary 8-OHdG: a marker of oxidative stress to DNA and a risk factor for cancer, atherosclerosis and diabetics. Clin Chem Acta 339: 1-9, 2004

25. Uchiyama M and Mihara M: Determination of malonaldehyde precursor in tissues by thiobarbituric acid test. Anal Biochem 86: 271-278, 1978

26. Toyokuni S: Reactive oxygen species-induced molecular damage and its application in pathology. Pathol Int 49: 91-102, 1999.

27. Rombouts K, Niki T, Wielant A, Hellemans K, Schuppan D, Kormoss N and Geerts A: Effect of aldosterone on collagen steady state levels in primary and subcultured rat hepatic stellate cells. J Hepatol 34: 230-238, 2001.

28. Alptekin N, Mehmetcik G, Uysal M and Aykac-toker G Evidence for oxidative stress in the hepatic mitochondria of bile duct ligated rats. Pharmacol Res 36: 243-247, 1997.
29. Li X, Meng Y, Wu P, Zhang Z and Yang X: Angiotensin II and Aldosterone stimulating NF-kappaB and AP-1 activation in hepatic fibrosis of rat. Regul Pept 138: 15-25, 2007.

30. Harada E, Yoshimura M, Yasue H, Nakagawa O, Nakagawa M, Harada M, Mizuno Y, Nakayama M, Shimasaki Y, Ito T, Nakamura S, Kuwahara K, Saito Y, Nakao K and Ogawa H: Aldosterone induces angiotensin-converting-enzyme gene expression in cultured neonatal rat cardiocytes. Circulation 104: 137-139, 2001.

31. Yamamuro M, Yoshimura M, Nakayama M, Abe K, Sumida H, Sugiyama S, Saito Y, Nakao K, Yasue H and Ogawa H: Aldosteron, but not angiotensin II, reduces angiotensin converting enzyme 2 gene expression levels in cultured neonatal rat cardiomyocytes. Circ J 72: 1346-1350, 2008. 